\title{
The United Nations Special Procedures system
}

Book

Accepted Version

Nolan, A., Freedman, R. and Murphy, T. (2017) The United

Nations Special Procedures system. Brill, pp472. ISBN

9789004304697 doi: https://doi.org/10.1163/9789004304703

Available at https://centaur.reading.ac.uk/66573/

It is advisable to refer to the publisher's version if you intend to cite from the work. See Guidance on citing.

To link to this article DOI: http://dx.doi.org/10.1163/9789004304703

Publisher: Brill

All outputs in CentAUR are protected by Intellectual Property Rights law, including copyright law. Copyright and IPR is retained by the creators or other copyright holders. Terms and conditions for use of this material are defined in the End User Agreement.

\section{www.reading.ac.uk/centaur}

\section{CentAUR}

Central Archive at the University of Reading

Reading's research outputs online 


\section{INTRODUCTION}

\section{Aoife Nolan, Rosa Freedman and Thérèse Murphy}

Described by Kofi Annan as the 'jewel in the crown' ${ }^{1}$ of the United Nations human rights system, the Special Procedures (SP) system is a key element of the expanding international framework for human rights protection and promotion. Since the first mandate was created in $1967,{ }^{2}$ laying the foundations for the system that we have today, we have seen a significant evolution in the role and functions of SP: from a concentration on mass violations of human rights to a consideration of individual petitions; from a small number of country-focussed mandates to (as of 1 July $2016^{3}$ ) 43 thematic mandates and 14 country ones; from being a minor and marginal part of the UN human rights framework to playing a crucial role in Human Rights Council and General Assembly sessions; from a mechanism of experts operating independently to one another to a coordinated system of mandate holders; from providing targeted reports on only very specific human rights issues to being a main source of information-sharing and reporting on a plethora of human rights threats across the globe; from operating largely under the radar to being the subject of significant state, civil society and academic expectations, resulting in harsh criticism when SP are regarded as having failed, or erred, in their work. ${ }^{4}$

However, while there has been extensive scholarship in relation to other aspects of the UN human rights system - such as the work of the UN treaty-monitoring bodies, the Human Rights Council, and the Office of the UN High Commissioner for Human Rights $(\mathrm{OHCHR})^{5}-$

\footnotetext{
${ }^{1}$ Kofi Annan referred to SP as 'the crown jewel of the [human rights] system' in a message to the 3rd Session of the Human Rights Council (HRC) on 29 November 2006: UN 'Secretary-General, in Message to Human Rights Council, Cautions against Focusing on Middle East at expense of Darfur, Other Grave Crises' (UN, 29 November 2006) <www.un.org/press/en/2006/sgsm10769.doc.htm> accessed 30 July 2016.

${ }^{2}$ UN Economic and Social Council Res 1235 (XLII) (6 June 1967) UN Doc E/4393.

${ }^{3}$ A new Independent Expert on violence and discrimination against SOGI was created at the HRC 32nd Session in June 2016: UNHRC Res 32/2, 'Protection against violence and discrimination based on sexual orientation and gender identity' (30 June 2016) UN Doc A/HRC/RES/32/2 (adopted as amended, by a recorded vote 23 to 18 , with 6 abstentions).

${ }^{4}$ A recent example of this point is the volubly negative reaction on the part of state actors, civil society, academics and others to the 2016 decision of the UN Working Group on Arbitrary Detention (WGAD) finding that Julian Assange was arbitrarily detained by the Governments of Sweden and the United Kingdom: WGAD 'Opinion No. 54/2015 concerning Julian Assange (Sweden and the United Kingdom of Great Britain and Northern Ireland)' (22 January 2016). A useful academic critique of the decision is provided in M Happold, 'Julian Assange and the UN Working Group on Arbitrary Detention' (EJIL: Talk!, 5 February 2016) <www.ejiltalk.org/julian-assange-andthe-un-working-group-on-arbitrary-detention/> accessed 30 June 2016.

5 Key recent and forthcoming examples of monographs and edited collections on these topics include: $\mathrm{H}$ Charlesworth and E Larking (eds), Human Rights and the Universal Periodic Review: Rituals and Ritualism (CUP 2015); R Freedman, The UN Human Rights Council: A Critique and Early Assessment (Routledge 2013); P Alston and F Megret (eds), The United Nations and Human Rights (2nd edn, OUP forthcoming 2016); H Keller and G Ulfstein (eds), UN Human Rights Treaty Bodies: Law and Legitimacy (CUP 2012); BG Ramcharan, The Law,
} 
there has been relatively little academic attention paid to the SP system. ${ }^{6}$ Moreover, the limited scholarship that does address SP frequently focusses on specific mandates as part of broader work on a specific human right or country situation. As such, little assessment has been undertaken of the system as a whole, including with regard to mandate holders' roles, functions, and the obstacles that they confront in their work. The lack of knowledge about the system impacts upon States, civil society, UN bodies and even mandate holders themselves.

This lacuna is ever more problematic given the growing profile and effectiveness of the SP's work, as well as the increasing attention and challenges that they face, both externally from States and internally from within the UN system. Given the current 'state of play' of the SP system, it is essential that careful attention and analysis be focussed on the strengths and weaknesses of the system. How does the SP system contribute to international human rights protection? How, when and why does it fail to do so? What steps can and should be taken to address shortcomings both within the system and in terms of the context in which it operates?

Conscious of - and deeply concerned about - these unanswered questions, the editors organised a workshop held at the University of Nottingham Human Rights Law Centre on 'The United Nations Special Procedures System' that took place in late 2014. The discussions sometimes strong disagreement - thrown up at that event served as the genesis of this volume which seeks to bring rigorous scholarly interrogation to bear on the Special Procedures.

In developing the collection, we felt it vital that the volume reflect as broad a range of perspectives as possible, incorporating both key players within, and commentators on, the SP system. Contributors include current and former mandate holders and those who assist them in their work, members of UN human rights treaty bodies, academics and members of civil society. The collection thus combines insights from internal participants in and external observers of the system. Moreover, to ensure that the collection as a whole reflects the theory, the practice and the politics of the system, we have included a number of shorter reflective, policy-oriented pieces written from a practice perspective, which sit alongside the more

Policy and Politics of the UN Human Rights Council (Brill 2015); F Gaer and C Broecker (eds), The United Nations High Commissioner for Human Rights: Conscience for the World (Brill 2014).

${ }^{6}$ Existing works on the Special Procedures system include: M Lempinen, Challenges Facing the System of Special Procedures of the United Nations Commission on Human Rights (Åbo Akademi University 2001); I Nifosi, The UN Special Procedures in the Field of Human Rights (Intersentia 2005); E Domínguez-Redondo, Los procedimientos publicos especiales de la Comision de Derechos Humanos de Naciones Unidas (Tirant lo Blanch 2005); BG Ramcharan, The Protection Roles of UN Human Rights Special Procedures (Martinus Nijhoff 2009); Special Edition of International Journal of Human Rights on 'The Role of the Special Rapporteurs of the United Nations Human Rights Council in the Development and Promotion of International Human Rights Norms', 15(2) (2011); T Piccone, Catalysts for Change: How the U.N. 's Independent Experts Promote Human Rights (Brookings Institution Press 2012). One notable recent addition is H Cantú Rivera (ed), The Special Procedures of the Human Rights Council (Intersentia 2015). 
conventional academic contributions. These shorter pieces by mandate holders and civil society members focus on specific aspects of their work within or in relation to the system, complementing the wider-ranging scholarly pieces. This variety of author perspectives and contribution types renders the collection well-placed to provide a holistic overview and comprehensive understanding of the SP system.

In terms of structure, the book is divided into three parts, with the first being focussed on the Special Procedures system as a 'system'. Here, contributors provide critical accounts of the Special Procedures' history (Domínguez-Redondo), major institutional issues affecting mandate holders (Connors), the role and challenges of country visits (Gaer), the part played by the Coordination Committee in supporting and facilitating SP (M'jid), and the ongoing reforms aimed at strengthening cooperation between SP and States (Limon).

The chapters in Part 2 focus on the actual work done by mandate holders, detailing the ways in which they have risen (or not) to the challenges and opportunities faced by them in the performance of their role(s). These range from advancing mandates in the face of trenchant state antagonism and non-cooperation (Shaheed and Parris Richter), to striking a balance between maintaining independence, ensuring state cooperation and fundraising work (Winkler and De Albuquerque), to developing working methods and internal rules and procedures where a SP is a collective body rather than an individual mandate holder (de Frouville), to SP taking advantage of the opportunities afforded by new information and communication technologies (McPherson and Probert). Other contributors to Part 2 focus on the role of mandate holders in developing international normative standards (Hohmann), in shaping, advancing (and sometimes hindering) the way in which changes occur in international human rights law (Davitti), and in addressing historic law and governance shortcomings in specific national contexts (Subedi). Part 2 closes with a consideration of the potential for using a mechanism that historically has been conceptualised in state-oriented terms to address the activities of powerful non-state actors (Hunt).

Part 3 moves on to locate the Special Procedures within a number of broader contexts. Evans' chapter is focussed on the role of SP within the wider UN architecture on torture. Fisher and Beswick address the international and the African regional SP systems, interrogating state engagement with both. Freedman and Crépeau consider the changing nature of the relationship between some Global North States and the SP system, while the central concern of Lynch's contribution is rooted in the dangerous reality of state intimidation or reprisal faced by many human rights defenders seeking to engage with the Special Procedures. 
Ultimately, the collection makes clear that there is much to praise about the system: SP have played a crucial role in providing material facts, reports and recommendations in monitoring and protecting human rights. Mandate holders have responded to the political, legal and resource-related contexts in which they operate by adopting a range of innovative working methods that have resulted in SP work having greater traction. ${ }^{7}$ The reports and other work produced by mandate holders have served as important landmarks in international human rights law norm-setting. ${ }^{8}$ SP have played a central part in identifying key rights-related issues and best practices. ${ }^{9}$ There have also been many steps forward in relation to the coherence of SP as a system, and to the harmonisation and coherence of working practices and streamlined methods for human rights protection and promotion. ${ }^{10}$ In recent years we have seen that ever more States and civil society actors have sought to strengthen SP, working together to ensure that this 'crown jewel' is preserved, polished and foregrounded within the UN human rights system. ${ }^{11}$ Indeed, despite its disjointed, uneven development in sometimes-hostile soil, despite its frequently cited shortcomings, and despite the attacks posed at different times from different quarters, ${ }^{12}$ the collection demonstrates that there is unquestionably a clearly defined and strongly established system of Special Procedures that has a set place and plays a key role in terms of the international human rights law architecture.

However, it is also evident from the collection that the ad hoc development of the SP system has given rise to significant problems in terms of the conceptualisation and effective functioning of the system. While some challenges have been overcome, many remain. In some ways, the system is a victim of its own success: at a logistical level, the proliferation of mandates - resulting in creation of mandates that are sometimes vague ${ }^{13}$ and overlapping ${ }^{14}$ has put significant pressure on resources and the capacity of the OHCHR to provide the support needed by mandate holders, threatening the effectiveness and efficiency of the system as a whole. ${ }^{15}$

\footnotetext{
${ }^{7}$ For more on this point, see the contributions of de Frouville, Winkler and De Albuquerque, McPherson and Probert, Hunt, and Subedi.

${ }^{8}$ For more on this point, see the contributions of Hohmann and Davitti.

${ }^{9}$ For more on the point of the role of mandate holders in identifying best practices, see the contributions of Shaheed and Parris Richter, and Winkler and De Albuquerque.

${ }^{10}$ For more on this point, see the contributions of Domínguez-Redondo and Connors.

${ }^{11}$ For more on this point, see the contributions of Limon, and Winkler and De Albuquerque.

${ }^{12}$ For more on this point, see the contributions of Gaer, Shaheed and Parris Richter, and Freedman and Crépeau.

${ }^{13}$ One often-cited example is the Independent Expert on Human Rights and International Solidarity established by UNCHR Res 2005/55 (20 April 2005) UN Doc E/CN.4/RES/2005/55.

${ }^{14}$ See eg the Special Rapporteur on Trafficking in Persons, Especially Women and Children and the Special Rapporteur on the Sale of Children, Child Prostitution and Child Pornography.

${ }^{15}$ For more on this point, see in particular the contributions of Connors, Winker and De Albuquerque, and Shaheed and Parris Richter.
} 
Other challenges relate to the structure of the SP system as it stands. As regards composition, concern remains about regional and gender representation in terms of SP mandate holders. ${ }^{16}$ And, as is evident from the collection, the system itself is non-uniform in terms of both the form and function of SP, with only limited provision for 'joined-up action' between mandate holders. ${ }^{17}$ There is only one annual meeting of SP per year, and March 2015 was the first time that the Coordination Committee of the Special Procedures presented an annual report to the Human Rights Council on the activities of the SP system as a whole. ${ }^{18}$ More broadly, relatively little is understood about SP outside the system, with even new mandate holders frequently having no knowledge of or exposure to the system prior to appointment. With regard to SP interplay with other parts of the UN system, SP coordination with other UN human rights entities such as treaty-monitoring bodies has not always been consistent and there is a clear need for greater cooperation between specific SP, OHCHR and other UN agencies. ${ }^{19}$

The chapters build on and develop the ever more extensive debate amongst States, academics, UN agencies and mandate holders themselves about the appropriate parameters of the role of SP. While the legitimacy of the system, which relies on States' consent, rests on its universal application, state-driven political processes are central to the way the system operates in practice. ${ }^{20}$ Indeed the part played by States - in creating, terminating and providing support to mandates, in engaging and cooperating (or not) with SP - has resulted in concerns about the politicisation of the system, not least because of recent efforts to control the independence of mandate holders through mechanisms such as the Code of Conduct, introduced in 2007, and appointments processes. Put differently, while the stature of the SP has increased, so too has state push-back. ${ }^{21}$ But so too has the capacity of SP to temper and resist state efforts to shackle their independence; for instance, while the Code of Conduct undoubtedly fetters SP in a range of ways, mandate holders were able to lobby effectively (with civil society allies) to fend off

\footnotetext{
${ }^{16}$ M Limon and T Piccone, 'Human Rights Special Procedures: Determinants of Influence. Understanding and Strengthening the Effectiveness of the UN's Independent Human Rights Experts' (Universal Rights Group, March 2014) $35<$ www.brookings.edu/ /media/research/files/reports/2014/03/19-un-human-rights-experts-evaluationpiccone/un-human-rights-experts-evaluation-piccone.pdf $>$ accessed 25 April 2015.

${ }^{17}$ For more on this point of joined-up action, see the contributions of M'jid, and Winkler and De Albuquerque.

18 OHCHR 'François Crépeau, the Chairperson of the Coordination Committee, presents the annual report of special procedures to the Council' (OHCHR, 18 March 2015) $<$ www.ohchr.org/EN/NewsEvents/Pages/DisplayNews.aspx?NewsID=15801\&LangID=E $>$ accessed 25 April 2015.

${ }^{19}$ For more on these points, see the contributions of Evans, M'jid, Connors, and Winkler and De Albuquerque.

${ }^{20}$ For more on this point, see in particular the contributions of Domínguez-Redondo, and Freedman and Crépeau.

${ }^{21}$ For an account of such state push-back, see P Alston, 'Hobbling the Monitors: Should U.N. Human Rights Monitors be Accountable?' (2011) 52 Harvard International Law Journal 561. For more on this point, see in particular the contributions of Shaheed and Parris Richter, Limon, and Freedman and Crépeau.
} 
an earlier draft that would have constrained SP far more severely than the Code that was ultimately adopted. ${ }^{22}$

This volume does not pretend to answer all the questions arising in relation to the SP system - the claim that any one book could do so is unsustainable. It does, however, provide comprehensive coverage and analysis of most, if not all, key aspects of that system. The conclusions in it will feed into reform proposals that will strengthen the SP system, including mainstreaming the work of mandate holders within the UN human rights system and throughout the UN Organisation as a whole as well as protecting the independence of those experts and ensuring that countries are not able to undermine Special Procedures. ${ }^{23}$ Contributions also make clear the ongoing challenges faced by mandate holders, identifying areas that must be strengthened to ensure that the roles, functions and work of SP are not blocked by States. Moreover, the collection demonstrates the fundamental part that external actors such as the Human Rights Council and OHCHR must play to ensure that attacks on the system do not succeed.

And serious threats clearly remain. Since 2014 it has become clear that States are becoming increasingly aware of the key role played by SP. This has been evidenced not only by their engagements with mandate holders but also in terms of efforts to block new mandates being created or to prevent specific individuals being appointed to mandates. March 2014 saw some States at the Human Rights Council block the list of new mandate holders presented by the Council President. ${ }^{24}$ That occurred ostensibly due to disagreement about the suitability of some individuals proposed for mandates (particularly in the context of Occupied Palestinian Territories mandate) ${ }^{25}$ and stated concerns about the regional and gender balance of appointees. ${ }^{26}$ However, according to many insiders although not formally documented, the blocking was at least in part attributable to the fact that some States were displeased by the Council's failure to appoint their nationals to mandates. More recently, during the June 2016

\footnotetext{
${ }^{22}$ For an account of the negotiations around the code of conduct highlighting the role of SP in this context, see Alston (n 21) 588-95. For further discussion of the Code of Conduct, see E Domínguez-Redondo, 'Rethinking the Legal Foundations of Control in International Human Rights Law: The case of Special Procedures' (2011) 29 NQHR 261.

${ }^{23}$ For more on these points, see the contributions of Connors and Limon to this collection. See also Limon and Piccone (n 16).

${ }^{24}$ This resulted in postponement of the approval of that list being required: UNHRC 'Report of the Human Rights Council on its twenty-fifth session' (17 July 2014) UN Doc A/HRC/25/2, paras 60-62.

${ }^{25}$ For more on this point, see R Freedman, 'Reform of selection process needed to strengthen Special Procedures' (International Service for Human Rights, 20 May 2016) <www.ishr.ch/news/reform-selection-process-neededstrengthen-special-procedures $>$ accessed 30 July 2016. The eventual appointee to that mandate, Makarim Wibinsono, was a candidate who had not been on the original shortlist at the March 2014 session.

${ }^{26}$ H Power, 'Special Procedures mandate-holders: The new intake (Universal Rights Group, 9 May 2014) $<$ www.universal-rights.org/blog/special-procedure-mandate-holders-the-new-intake/> accessed 30 July 2016.
} 
session of the Human Rights Council, many States first sought to block the creation of a new mandate on Sexual Orientation and Gender Identity minorities, ${ }^{27}$ followed the next day by Russia attempting to block the list of proposed mandate holders, ${ }^{28}$ forcing the day's session to run late into the night and be carried over to an additional date one week later. These incidents are not simply reflective of state discomfort with specific human rights issues and/or individuals. Rather, they show that States are increasingly aware of the central role that Special Procedures play in the international human rights system, and that mandate holders' work can have significant impact.

Ultimately, any future efforts to defend, strengthen and reform the SP system so as to advance the effective promotion and protection of human rights will only be effective if based on an accurate understanding of Special Procedures, their work and functions, and the system's strengths, weaknesses, and challenges. It is the editors' hope and belief that this collection will provide the necessary tools to those seeking to carry out this vital work.

The information in the collection reflects the state of play on 1 June 2015, unless otherwise specified by chapter authors.

\footnotetext{
${ }^{27}$ For more on this point, see 'An L.G.B.T. Watchdog at the United Nations' (New York Times, 1 July 2016) $<$ http://mobile.nytimes.com/2016/07/02/opinion/an-lgbt-watchdog-at-the-unitednations.html?ref=opinion\&referer=https://t.co/GSGlfKOKwy\&_r=0> accessed 30 July 2016.

${ }^{28}$ Universal Rights Group, 'Report on the 32nd Session of the Human Rights Council' (URG, 11 July 2016) $<$ www.universal-rights.org/urg-human-rights-council-reports/report-32nd-session-human-rights-council/> accessed 30 July 2016.
} 